Review

\title{
Emerging Role of Vitamin D and its Associated Molecules in Pathways Related to Pathogenesis of Thrombosis
}

\author{
Syed Mohammad, Aastha Mishra and Mohammad Zahid Ashraf* \\ Department of Biotechnology, Faculty of Natural Sciences, Jamia Millia Islamia, New Delhi 110025, India; \\ mahmudaga@gmail.com (S.M.); aastha0602@gmail.com (A.M.) \\ * Correspondence: zashraf@jmi.ac.in
}

Received: 28 June 2019; Accepted: 12 September 2019; Published: 24 October 2019

\begin{abstract}
Vitamin D, besides having an essential role in calcium and bone metabolism, also acts as a mediator of many non-calcemic effects through modulations of several biological responses. Vitamin D exists in its two major forms, vitamin $\mathrm{D}_{2}$, or commonly known as ergocalciferol, and vitamin $\mathrm{D}_{3}$, or commonly known as cholecalciferol. Both of these forms bind to vitamin D-binding protein to get transported to all vital target organs, where it serves as a natural ligand to vitamin D receptors for enabling their biological actions. Clinical reports corroborating vitamin D deficiency with an increase in thrombotic episodes implicate the role of vitamin D and its associated molecule in the regulation of thrombosis-related pathways. Thrombosis is the formation and propagation of a blood clot, known as thrombus. It can occur either in the arterial or the venous system resulting in many severe complications, including myocardial infarction, stroke, ischemia, and venous thromboembolism. Vitamin D, directly or indirectly, controls the expression of several genes responsible for the regulation of cellular proliferation, differentiation, apoptosis, and angiogenesis. All of these are the processes of potential relevance to thrombotic disorders. This review, thus, discussed the effects of vitamin D on pathways involved in thrombosis, such as hemostatic process, inflammatory pathway, and endothelial cell activation, with a focus on the molecular mechanisms associated with them.
\end{abstract}

Keywords: vitamin D; thrombosis; coagulation pathway; inflammation; activated endothelial cells

\section{Background}

Vitamin D is a lipophilic, secosteroid hormone, which majorly exists in two forms-vitamin $\mathrm{D}_{2}$ and vitamin $\mathrm{D}_{3}$. Vitamin $\mathrm{D}_{2}$, commonly known as ergocalciferol, is manufactured through the ultraviolet irradiation of ergosterol from yeast [1]. It cannot be synthesized inside the human organism but can enter blood circulation with dietary sources, such as mushroom, supplementation, and fortification [2]. Vitamin $\mathrm{D}_{3}$, commonly known as cholecalciferol, is the only form produced in the human organism that is synthesized in the skin through the ultraviolet irradiation of 7-dehydrocholesterol. It can also be obtained from sources like fatty fish, egg and dairy products, and dietary supplements. In mammals, synthesis of vitamin $\mathrm{D}_{3}$ gets initiated in the epidermis, with cleavage of the $\mathrm{B}$ ring of 7-dehydrocholesterol, under UVB radiation of wavelength 290 to $315 \mathrm{~nm}$. This gives rise to an extremely unstable previtamin $\mathrm{D}_{3}$, which upon spontaneous isomerization, is converted to a precursor molecule, vitamin $\mathrm{D}_{3}$ [3]. This is then converted to 25-hydroxy vitamin $\mathrm{D}_{3}\left(25(\mathrm{OH}) \mathrm{D}_{3}\right)$ in the liver by enzyme 25-hydroxylase [4]. Similarly, vitamin $\mathrm{D}_{2}$ after ingestion undergoes a 25-hydroxylation step in the liver, yielding 25-hydroxy vitamin- $\mathrm{D}_{2}\left(25(\mathrm{OH}) \mathrm{D}_{2}\right)[5]$. Both $25(\mathrm{OH}) \mathrm{D}_{2}$ and $25(\mathrm{OH}) \mathrm{D}_{3}$ are further subjected to a second hydroxylation step in the kidney to produce hormonally active forms, 1,25-dihydroxyvitamin $\mathrm{D}_{2}\left(1,25(\mathrm{OH})_{2} \mathrm{D}_{2}\right)$ and 1,25-dihydroxyvitamin $\mathrm{D}_{3}\left(1,25(\mathrm{OH})_{2} \mathrm{D}_{3}\right)$, respectively [5]. 25-hydroxy vitamin 
$\mathrm{D}(25(\mathrm{OH}) \mathrm{D})$, reflecting the concentrations of both $25(\mathrm{OH}) \mathrm{D}_{2}$ and $25(\mathrm{OH}) \mathrm{D}_{3}$, is routinely determined to assess vitamin $\mathrm{D}$ status in clinical practices [6]. It has been observed that vitamin $\mathrm{D}_{3}$ is more efficacious at raising concentrations of serum $25(\mathrm{OH}) \mathrm{D}$ than $\mathrm{D}_{2}[7,8]$. This could be attributed to the fact that vitamin $\mathrm{D}_{3}$ has a higher affinity for vitamin $\mathrm{D}$ binding protein as well as for the vitamin $\mathrm{D}$ receptor and is also the preferred substrate for the hydroxylase enzyme in the liver in comparison to vitamin $D_{2}$ [9]. Further, vitamin $D_{2}$ is observed to be considerably less stable than vitamin $D_{3}$ [10].

Vitamin D deficiency is a highly prevalent condition, affecting about 30-60\% of the general population worldwide [11-13]. It is conventionally considered to be the main factor in skeletal homeostasis and in the prevention of rickets in children and osteomalacia and osteoporosis in adults [14-17]. In addition to its classical role in bone metabolism, it has been demonstrated that vitamin $\mathrm{D}$ is also a crucial agent for decreasing the risk of cardiovascular disorders (CVDs), malignancies, and immune system disease [18-23]. The significance of this biomolecule could be demonstrated by the fact that almost a $7 \%$ reduction in all-cause mortality can be attained by adequate serum vitamin $\mathrm{D}$ levels and are expected to ease the economic burden of diseases [24-26]. Epidemiological data indicate that deficiency of vitamin $\mathrm{D}$ is common among CVDs patients with circulating 25(OH)D levels less than $20 \mathrm{ng} / \mathrm{mL}$ [11]. Similarly, a reduced plasma level of $25(\mathrm{OH}) \mathrm{D}$ of around $25 \mathrm{ng} / \mathrm{mL}$ has been associated with an increased risk of hypertension $[27,28]$. A population-based study and meta-analyses associated very low levels of 3-4.8 ng/mL of plasma $25(\mathrm{OH}) \mathrm{D}$ levels with an increase in multivariable-adjusted risk by $40 \%$ for ischemic heart disease, by $64 \%$ for myocardial infarction (MI), and by $57 \%$ for early death when compared with the individuals having plasma 25(OH)D levels of 18.83-28.44 ng/mL [29]. All these data suggest that the deficiency of vitamin D levels is an alarming risk factor for such diseases. Table 1 provides the vitamin D status, viz. severely deficient, deficient, insufficient, and recommended level as per the serum levels of vitamin D in the body. The serum levels of vitamin D less than $20 \mathrm{ng} / \mathrm{mL}$ is considered to be deficient in the human body.

Table 1. Status of vitamin D level as provided by the Institute of Medicine* and Endocrine Society ${ }^{* *}$.

\begin{tabular}{ccc}
\hline Vitamin D Status & Institute of Medicine & Endocrine Society \\
\hline Severely deficient & $0-10 \mathrm{ng} / \mathrm{mL}$ & $0-10 \mathrm{ng} / \mathrm{mL}$ \\
Deficient & - & $10-20 \mathrm{ng} / \mathrm{mL}$ \\
Insufficient & $10-20 \mathrm{ng} / \mathrm{mL}$ & $20-30 \mathrm{ng} / \mathrm{mL}$ \\
Recommended level & $20-50 \mathrm{ng} / \mathrm{mL}$ & $30-100 \mathrm{ng} / \mathrm{mL}$ \\
\hline
\end{tabular}

\footnotetext{
* Institute of Medicine is a non-profit organization established by National Academy for science, USA, for science-based advice on biomedical science, medicine, and health [30]. ${ }^{* *}$ Endocrine Society is a professional, international medical organization, USA, in the fields of endocrinology and metabolism [31].
}

Vitamin D is a key metabolite with diverse metabolic processes in the human body. Its active forms bind to vitamin D binding protein (DBP) so that they get transported to all the vital target organs of the body. These active forms then serve as a natural ligand to vitamin D receptor (VDR) and bring about the biological functions of vitamin D [32,33]. VDR is a ligand-active transcription factor that plays a vital role in regulating the expression of several genes involved in calcium phosphate homeostasis [34]. VDR is distributed throughout the body in various cells and tissues, such as the epithelial cells of the small intestine, large intestine, distal tubule of kidneys, parathyroid, bronchus, thymus, prostate gland, mammary gland, endothelial cells, and the cells of the osteoblasts in bones [35-37]. VDR has also been identified in most of the immune cells, notably in macrophages, dendritic cells, and lymphocytes, and has shown to be involved in the regulation of inflammatory and immune responses [38-41]. Inflammation and hemostasis are the two complex pathophysiological processes that are interrelated to each other. The activation of both the systems is interdependent in a positive feedback loop with one process promoting the effects of the other process and vice versa. This crosstalk involves procoagulant factors, pro-inflammatory cytokines, chemokines, adhesion molecules, tissue factor (TF) expression, platelets, and endothelial cells [42]. These all mediators trigger the prothrombotic tendency by an increase of platelet reactivity, endothelial dysfunction, activation of 
the coagulation cascade, and suppression of natural anticoagulant pathways, as well as fibrinolytic activities [43]. Therefore, it becomes imperative to consider the influence of vitamin D and VDR in the thrombosis pathophysiology.

Thrombosis is the formation and propagation of a blood clot, known as a thrombus, in the either arterial or venous system. It generally occurs when there is a disturbance in the balance between clot formation and its dissolution [44]. Red blood cells and fibrins are the major contenders of the "red clot" seen in venous thrombosis, while aggregated platelets are the major contenders of the "white clot" seen in arterial thrombosis [45]. Virchow famously postulated three main causes of thrombosis: stasis of blood, change in the vessel wall, and change in the composition of blood [46]. Venous thrombosis has been associated with hypercoagulability (composition change) and reduced blood flow (stasis), whereas arterial thrombosis has been linked to endothelium disruption and platelet activation [47]. However, this traditional view of perceiving venous and arterial thrombosis as two different entities has been challenged recently. Patients with arterial thrombosis are also at the risk of developing venous thrombosis, and overlapping risk factors are associated with both arterial and venous thrombosis [48]. Furthermore, several novel factors have emerged in the pathogenesis of thrombosis. Plasma levels of vitamin D metabolites and its associated molecules are one of them that have appeared to be an intriguing factor involved in regulatory processes related to thrombosis [49]. There are shreds of evidence from the clinical reports that have correlated deficiency of vitamin $\mathrm{D}$ with the increase in thrombotic episodes [50,51]. Besides, Vitamin D, directly or indirectly, controls the expression of more than 200 genes, such as epidermal growth factor receptor, phospholipase $C$, gamma 1, Insulin growth factor binding protein 3 , and many more, that are responsible for the regulation of cellular proliferation, differentiation, apoptosis, and angiogenesis [52]. These are the processes of potential relevance to thrombotic disorders. This review, therefore, tried to provide currently available data on the effects of vitamin D on coagulation factors, inflammatory cells, and endothelial cells that are involved in the thrombus formation with a special focus on their molecular mechanisms. We have also summarized recent progress related to favorable anti-thrombotic actions of vitamin $\mathrm{D}$ in tissues that are directly or indirectly involved in the thrombotic processes.

\section{Role of Vitamin $D$ in the Coagulation Pathway}

Hemostasis is a dynamic process that maintains a balance between the clot formation and the mechanism that inhibits the clot [53]. The thrombogenic components of the body comprise of TF, prothrombin, fibrinogen, von Willebrand factor, collagen, platelet-activating factor, platelets, and activated endothelium. While the anti-thrombogenic components are antithrombin, plasminogen, tissue plasminogen activator, heparin, thrombomodulin, and protein C and S [53]. The anti-thrombotic effects of vitamin D on these thrombogenic and anti-thrombogenic components of the coagulation system have been very well documented $[51,54,55]$. A recent study demonstrated the association of low vitamin D levels with the development of deep venous thromboembolic (DVT) events in patients with ischemic stroke [51]. Likewise, a case-control study observed that the concentration of 25(OH)D was significantly lower in 82 participants with idiopathic lower-extremity DVT as compared to 85 sex and age-matched healthy participants [50]. Further, Blondon et al. [56] found a protective effect of vitamin D supplementation on the risk of unprovoked venous thromboembolism (VTE) and women with low vitamin D concentrations. This finding suggests that vitamin D deficiency could be treated as an undiagnosed risk factor for unprovoked VTE that constitutes around 40\% cases of all VTE [56].

The effects of vitamin D metabolites through the noncalcemic actions of VDR ligands could be attributed to these antithrombotic effects of vitamin D [52]. A murine model-based study demonstrated the antithrombotic action of VDR through their VDR knock out (KO) mice fed either on high calcium or regular calcium diet. They found that platelet aggregation was enhanced and gene expression of antithrombin (AT) in the liver and thrombomodulin (TM) in the aorta, liver, and kidneys was downregulated in their $\operatorname{VDR}(\mathrm{KO})$ mice irrespective of their calcium diet. Whereas, TF expression in the liver and kidney was upregulated [57]. All of these results in their in vivo model elicit the role of 
VDR in the maintenance of antithrombotic homeostasis. Similarly, Ohsawa et al. [58] demonstrated the effects of $1,25(\mathrm{OH})_{2} \mathrm{D}_{3}$ and its potent synthetic analogs on TF and TM gene expressions when stimulated by tumor necrosis factor (TNF), lipopolysaccharides (LPS), and oxidized LDL (ox-LDL). They found that like $1,25(\mathrm{OH})_{2} \mathrm{D}_{3}$, its synthetic analogs downregulated $T F$ and upregulated TM expressions, counteracting the effects of TNF and ox-LDL in monocytic cells. Perhaps, the biological activity of these analogs is mediated by VDR as these analogs have shown to have a higher affinity for VDR. These potent analogs may be further utilized for studying the molecular mechanisms of TF and $\mathrm{TM}$ regulation and might serve as adjunctive antithrombotic agents in the treatment of inflammatory and atherosclerotic diseases [58]. Similarly, Martinez-Moerno and colleagues investigated the impact of vitamin D molecules, calcitriol, and paricalcitol on the TF expression induced by a pro-inflammatory cytokine, TNF- $\alpha$ in human aortic vascular smooth muscle cells (VSMCs). Both calcitriol and paricalcitol, are a man-made active form of vitamin D. Their study demonstrated increased TF expression and procoagulant activity in a nuclear factor- $\kappa \mathrm{B}(\mathrm{NF}-\kappa \mathrm{B})$ dependent manner in VSMCs incubated with TNF- $\alpha$. This was accompanied by the upregulation of TF signaling mediator protease-activated receptor 2 (PAR-2) expression. However, upon treatment with calcitriol and paricalcitol, TNF- $\alpha$-induced TF expression and activity associated with downregulation of NF- $\mathrm{B}$ signaling and PAR-2 expression were significantly blunted, the levels of VDR were restored, and the expression of TF pathway inhibitor (TFPI) was enhanced [59]. An anti-coagulation protein, TFPI, acts as a dual inhibitor of coagulation by binding to both TF/Factor VIIa complex as well as Factor Xa [60]. One of the studies, in fact, found a significant positive association between more than $20 \mathrm{ng} / \mathrm{mL}$ levels of $25(\mathrm{OH}) \mathrm{D}_{3}$ and TFPI levels [61]. Furthermore, Toderici et al. described the transcriptional regulation of $A T$ gene by vitamin D and described the functional and pathological relevance of mutations affecting the VDR elements of $A T$ gene. Their study identified regulatory mutations in the AT gene resulting in AT deficiency and the risk of thrombosis. These regulatory mutations were found to disrupt potential VDR elements present in the promoter region of the gene, suggesting the crucial role of vitamin D on its regulation [62].

Furthermore, VDR has recently been found in human platelets and a megakaryocyte lineage [63]. Platelets are critically important mediators of the coagulation pathway, activating the TF-mediated processes and contact-arms of the coagulation cascade $[64,65]$. Larger platelets are shown to be more reactive and have greater pro-thrombotic potential. The elevated mean platelet volume (MPV) is associated with increased risk for DVT and MI in a large sample size study, supporting the concept that platelet reactivity is indispensable in the pathogenesis of venous thromboembolism [66]. Furthermore, a recent study has associated the increase in MPV with a decrease in serum $25(\mathrm{OH}) \mathrm{D}$ concentrations in patients with stable coronary artery disease, suggesting further linkage of vitamin $\mathrm{D}$ to thrombosis and hemostasis [55]. They concluded that there exists a negative correlation between MPV and serum $25(\mathrm{OH}) \mathrm{D}$ concentration, with MPV highest in group of patients with $25(\mathrm{OH}) \mathrm{D}$ concentration $<10$ $\mathrm{ng} / \mathrm{mL}$, moderate in group with the concentration of $10-20 \mathrm{ng} / \mathrm{mL}$, and lowest in group with the concentration $>20 \mathrm{ng} / \mathrm{mL}$.

\section{Role of Vitamin D in Inflammatory Pathways}

Evidence of an intrinsic link between innate inflammatory system and coagulation challenges the definition of pathological thrombosis, as described by Virchow [46]. In 2013, Engelmann and Massberg coined the term immunothrombosis, describing a process by which the activation of coagulation assists the function of the innate immune system, and the converse, whereby components of the immune system contribute to thrombosis [67]. Recently, a study from our lab demonstrated the crucial role of sterile inflammation in the thrombotic events and also established that inflammation precedes coagulation in thrombosis [68]. Our study showed a direct association between nucleotide-binding domain, leucine-rich-containing family, pyrin domain containing 3 (NLRP3) inflammasome complex and hypoxia-inducible factor 1-alpha (HIF-1 $\alpha)$ in hypoxia-induced thrombosis. We also observed a concomitant increase in the relative expression of NLRP3, caspase-1, interleukin- $1 \beta$ (IL-1 $\beta$ ), and interleukin-18 (IL-18) transcripts in the individuals with clinically established venous thrombosis [68]. 
Additionally, Yadav et al. demonstrated the orchestration of venous thrombosis under normal oxygen concentration by the increased activation of NLRP3 inflammasome and IL-1 $\beta$ release in their CD39-deficient mice [69].

$\mathrm{TF}$, a key initiator for in vivo activation of the extrinsic pathway of coagulation, is one of the links between inflammation and coagulation. Inflammatory mediators promote coagulation by elevating the production of TF. Normally, TF is present in the circulations but at a very low level; however, an increase of TF expression and its interaction with platelets and coagulation factors tend to shift the hemostatic balance in favor of coagulation or thrombosis $[64,65]$. Platelets store and release not just those biologically active substances required for coagulation and vascular integrity, but it also contains substances, including growth factors, cytokines, and chemokines, that affect immunological responses [70]. Platelets interact with neutrophils, monocytes, and lymphocytes to activate them and are simultaneously responsible for the initiation and amplification of venous thrombosis [71]. Functional Toll-like receptors (TLRs), such as TLR-2, TLR-4, and TLR-9, expressed on platelets also provide a potential link to innate immunity with thrombosis [72]. The multifaceted role of fibrinogen, an acute phase reactant, in tissue injury and inflammation also provides the connection between these two pathways. Studies have shown the deposition of fibrinogen in both inflammatory conditions and tissue injury. Thus, all of these points of commonality reflect the close connection of inflammation and thrombosis [73].

Vitamin D has been instrumental in the proliferation, differentiation, and functions of immune cells, both directly and indirectly. Dendritic cells and macrophages are known to express enzymes, 25-hydroxylase and 1-alpha-hydroxylase, required for converting vitamin $\mathrm{D}$ to its activated form, i.e., $1,25(\mathrm{OH})_{2} \mathrm{D}$, whereas, activated $\mathrm{T}$ cells can hydrolyze $25(\mathrm{OH}) \mathrm{D}$ to $1,25(\mathrm{OH})_{2} \mathrm{D}[74-76]$. A study demonstrated that vitamin D inhibited the production of pro-inflammatory cytokines, like IL-6 or TNF- $\alpha$, in monocytes/macrophages via the inhibition of p38 MAP kinase [77]. Zhang et al. identified that a dose of vitamin D stimulated and upregulated the expression of MAPK phosphatase-1, which dephosphorylated p38 and inhibited p38 phosphorylation and inactivation, thereby inhibiting the production of pro-inflammatory cytokines, IL-6, and TNF- $\alpha$ production in LPS-stimulated human monocytes [77]. Another study demonstrated the profound anti-inflammatory effect of vitamin D on peripheral and intestinal $\mathrm{T}$ cells from inflammatory bowel disease patients. They incubated peripheral and intestinal T-cells with $1,25(\mathrm{OH})_{2} \mathrm{D}$ that resulted in a significant reduction in frequencies of pro-inflammatory $\mathrm{T}$ cells producing IFN- $\gamma$, IL-17, IL-22, IL-9, and TNF [78]. Furthermore, $1,25(\mathrm{OH}) 2 \mathrm{D}_{3}$ has been reported to decrease the expression of transcription factors, NF- $\mathrm{B}$, leading to an anti-inflammatory effect [79].

\section{Role of Vitamin D in the Endothelial Cell Activation}

The vascular endothelium is located strategically at the interface between tissue and blood, which is an ideal position, to modulate the entire cardiovascular system. Endothelial cells (ECs) play an essential role in the maintenance of vascular tone, transport of nutrients and solutes across the endothelium. It also plays an active role in the maintenance of a thrombo-resistant surface through the activation and inactivation of various vasoactive hormones [80]. Under normal conditions, ECs provide a non-thrombogenic surface, which prevents the adhesion of the platelets or other blood cells and does not activate the coagulation cascade [81]. Under physiological conditions, the anticoagulant role of ECs is largely mediated by TFPI, thrombomodulin, endothelial progenitor cell receptor, heparin-like proteoglycans, and platelet inhibitors, such as nitric oxide and prostacyclin. However, once ECs become activated, they become pro-thrombotic. For example, activated endothelial cells express TF and play an active role in the generation of thrombin [82]. Similarly, activated ECs also express a variety of molecules, such as von Willebrand factor, P-selectin, angiopoietin-2, and endothelin-1 (ET-1), which are the active participants of a variety of processes, such as platelet adhesion, leukocyte recruitment, inflammation modulation, and vasoconstrictor [83,84]. 
Few interventional studies have demonstrated the improvement in endothelial functions on treatment with vitamin D $[85,86]$. Studies suggest that vitamin D improves endothelial function $[87,88]$ and reduces the production of inflammatory cytokines [89]. It may also cause a decrease in endothelial adhesion molecules, an increase in NO production, and the reduction of platelet aggregation $[57,90,91]$. Other potential mechanisms linking vitamin $\mathrm{D}$ to vascular health include the decrease in oxidative stress [89] and attenuation of NF- $\mathrm{KB}$ activation [92]. NF- $\mathrm{KB}$ signaling molecules regulate the activation of ECs by giving rise to a pro-adhesive and pro-coagulant phenotype with a concomitant reduction of the ECs barrier function [93]. The key target genes of NF-kB in the ECs include adhesion molecules, such as vascular cell adhesion molecule 1 (VCAM-1), intercellular adhesion molecules 1 (ICAM-1), and E-selectin that mediates adherence of inflammatory cells, including neutrophils, monocytes, lymphocytes, and monocytes, to the vascular wall and triggering their extravasation into tissue [94-97].

Expression of VDR and its ligand-generating enzyme, 1-alpha-hydroxylase, in ECs [98] suggests that they possess the capability for orchestrating local vitamin D dependent regulatory activity that is confined to a vascular cell. Furthermore, vitamin D stimulates the production of vasoactive factors in human ECs culture [99]. Calcitriol upregulated the ET-1 and NO production via VDR-dependent activation as the effects were shown to get disappeared when the VDR gene was silenced. However, the mechanism involved in the upregulation of each factor differed. While ET-1 upregulation was regulated by activator protein-1 (AP-1) activation, the upregulation of $\mathrm{NO}$ via endothelial nitric oxide synthase (eNOS) was controlled directly by VDR activation. This group also evaluated the in vivo consequence of injecting a single intraperitoneal injection of $400 \mathrm{ng} / \mathrm{kg}$ calcitriol in normal rats and euthanized them $24 \mathrm{~h}$ later. Calcitriol increased the production and expression of both factors in the rats, confirming the results observed in the endothelial cell culture [99]. A study showed that even a presumed inactive sterol, cholecalciferol, is a potent mediator of endothelial stability at physiologically relevant levels in a VDR-independent manner. This research study found that the stabilizing effect was non-genomic and occurred in conjunction with the deactivation of ADP-ribosylation factor-6 (ARF-6), RhoA deactivation, and stabilization of vascular endothelial-cadherin at the plasma membrane [100].

In another study, expression of eNOS was shown to be reduced by $50 \%$ in aortic tissue of VDR gene knockout when compared with the wild type mice [54]. A research paper employing an endothelial-specific knockout of the murine $V D R$ gene showed a significant impairment in acetylcholine-induced aortic relaxation [101]. This was accompanied by a reduction in eNOS expression and phosphor-vasodilator-stimulated phosphoprotein levels in the aorta as compared to control mice [101]. Furthermore, brachial artery flow-mediated dilation, a measure of endothelium-dependent dilation in vivo, was lower in vitamin D insufficient group. In this study, flow-mediated dilation was positively related to serum $25(\mathrm{OH}) \mathrm{D}$ but not $1,25(\mathrm{OH}) 2 \mathrm{D}$ concentration. They also observed that vascular ECs expression of $\mathrm{p} 65$ subunit of NF- $\mathrm{kB}$, pro-inflammatory nuclear transcription factor, and IL-6, a pro-inflammatory cytokine downstream target of NF- $\mathrm{kB}$, was greater in vitamin D deficient subjects when compared to their vitamin D sufficient subjects [93].

Suppression of the rennin-angiotensin-aldosterone system (RAAS) and positive effects on endothelial function [87] and vascular structure [102] are reported among the most reliable mechanisms explaining the influence of vitamin D on the cardiovascular system. The suppression of RAAS by VDR activation has been documented by using in vitro experiments [103] and animal models [104]. Human observational data confirm this inverse relation between RAAS parameters and 25(OH)D levels $[105,106]$. A study on thirty-three consecutive patients with essential hypertension and hypovitaminosis D underwent therapy with cholecalciferol for 8 weeks. At the end of the study, vitamin D levels were found to be normal, and the restored vitamin D levels inhibited peripheral RAAS system with the improvement in flow-mediated dilation in patients with essential hypertension and hypovitaminosis D [107].

Wei Xu et al. studied the effect of vitamin D on endothelial progenitor cells (EPCs) pretreated with AngII. Their study demonstrated that vitamin D reversed AngII-induced oxidative stress injury by the peroxisome proliferator-activated receptor- $\gamma($ PPAR- $\gamma)$ pathway [108]. PPAR- $\gamma$ lowers the production 
of superoxide and enhances the repair capacity of EPCs [109]. It also protects the EPC function against oxidative stress [110]. Ang II induces the production of reactive oxygen species and activates the transcription factor NF-kB. This induces several cytokines, such as TNF- $\alpha$, IL-6, ICAM-1, VCAM-1, and E-selectin. The induction of these cytokines prompts vascular injury [111]. Schröder and group investigated the endothelial barrier characteristics of endothelial colony-forming cells (ECFCs) and the effect of vitamin D on cell-cell adhesion and barrier integrity of ECFCs monolayer under inflammatory conditions. ECFCs are a specific and well-defined sub-population of EPCs, participating in endothelial repair with the high proliferative ability of de novo vessel formation. Their study showed that Vitamin D treatment enhanced ECFC mobilization through vascular endothelial cadherin phosphorylation. Vitamin D treatment alleviated inflammation in ECFCs monolayer that resulted in higher ECFC barrier integrity [112]. All of these studies suggest the significant role of vitamin D on endothelial functions and its deficiency in the dysfunctioning of these cells.

\section{Anti-Thrombotic Actions of Vitamin D}

Several studies have highlighted the anti-thrombotic actions of vitamin D [51,54,55]. A pilot randomized control trial was done on forty vitamin D deficient patients with DVT or pulmonary embolism (PE) [113]. After three months of treatment with vitamin D supplementation, the researchers found enhancement in the anticoagulant effect of warfarin, i.e., those patients who were given vitamin $\mathrm{D}$ used significantly lower doses of warfarin as compared to the placebo. Another study demonstrated that cholecalciferol supplementation in stable, moderate chronic kidney disease patients was associated with an improved vascular endothelial function. Supplementation of vitamin D resulted in a significant decrease in parathyroid levels and also reduced the levels of circulating biomarkers of endothelial function, including E-selectin, VCAM, and ICAM-1 [114].

A prospective study on a cohort comprising of 40,000 women drawn from the southern Swedish population followed for a mean period of 11 years concluded that women with a habit of more active sun exposure were at a 30\% lower risk of VTE than those who did not [115]. Women exposing themselves to the sun or artificial UVB light more often, presumably improve their vitamin D status [116]. Moreover, the risk of VTE increases by $50 \%$ in winter, during which vitamin D has been demonstrated to be the lowest [117], as compared to the other seasons.

Furthermore, a randomized controlled study of 250 patients with prostate cancer, half of whom were given 45 micrograms of $1,25(\mathrm{OH})_{2} \mathrm{D}_{3}$ weekly, found an unexpected significantly lower risk of thrombotic events [118]. A double-blind, placebo-controlled randomized trial in Scotland showed significant improvement in flow-mediated vasodilation of brachial artery and also decreased blood pressure with a single dose of $100,000 \mathrm{IU}$ vitamin $\mathrm{D}_{2}$ to patients with type-2 diabetes [85]. However, few studies did not find any effect of vitamin D supplementation $[117,118]$. An interventional pilot study screened 76 Caucasian patients with peripheral artery disease for vitamin D deficiency and found that vitamin D supplementation increased serum 25-(OH)D levels without influencing endothelial function, arterial stiffness, coagulation parameters, such as thrombin, antithrombin, D-dimer, plasminogen activator inhibitor-1, and inflammation parameters, such as c reactive protein [119]. Another study found no effect on the improvement of markers of vascular function, such as blood pressure and total cholesterol with vitamin D supplementations, in patients with a history of MI [120].

\section{Future Perspectives}

Vitamin D has established itself as a key regulatory molecule in normal physiological processes and has shown tremendous promise as a predictive/therapeutic tool. There are ample studies, correlating lower doses of vitamin D with thrombosis [115-118]; however, the exact molecular mechanism of the pathophysiological role of lower doses of vitamin D is still obscure. It is now obvious that vitamin D has several non-calcemic consequences, which, when investigated, could lead us to the genesis of thrombosis that remains a conundrum to the scientific community. Vitamin D is critical at high altitudes since its levels are usually found to be drastically low as a consequence of the 
surrounding environment, such as excessive clothing due to extreme cold and harsh sunlight [121]. Furthermore, hypoxic environment facilitates the pro-thrombotic environment $[68,122]$. Therefore, it would be really interesting to hypothesize that exposure to high altitude hypoxia might perturb the expression and physiology of vitamin $\mathrm{D}$, which in turn potentiates the onset of prothrombotic phenotypes via activation of NLRP3 inflammasomes-mediated inflammation. The conductance of such studies analyzing the differential plasma concentration of vitamin D and associated molecules at high altitude and their association with thrombotic episodes would add a new dimension to the thrombosis biomarker discovery. It would also provide the clue towards the integrated involvement of hypoxia-vitamin D-NLRP3 inflammasome triad contribution to the underlying mechanisms of vascular dysfunction/hypercoagulation under hypoxia. Our lab has conducted a preliminary unpublished study that observed a substantial effect of hypobaric hypoxia exposure on vitamin D concentration in both healthy persons and thrombotic patients at high-altitude. Our study observed that the changes in vitamin $\mathrm{D}$ concentration in thrombotic patients were much severe as compared to healthy exposed persons at high altitudes. The extension of such a study can also explore the potential of vitamin $D$ to be used as therapeutic interventions for the efficient prevention of hypoxia-induced thrombotic disorders. To conclude, the understanding of vitamin D expression behavior under hypoxia and advances in the implication of the understanding in the context of thrombosis would help us in the translational application that could be beneficial in the prevention of several other lethal cardiovascular disorders.

Author Contributions: S.M. designed, drafted the article and contributed to extensive literature review for the article. A.M. participated in designing, drafting, and critical revision of the article. M.Z.A. conceptualized, designed, and critically revised the article.

Funding: This research was funded by research grant number BT/PR29626PFN/20/1397/2018 by Department of Biotechnology, Government of India.

Conflicts of Interest: The authors declare no conflict of interest.

\section{References}

1. Japelt, R.B.; Jakobsen, J. Vitamin D in plants: A review of occurrence, analysis, and biosynthesis. Front. Plant Sci. 2013, 4, 136. [CrossRef] [PubMed]

2. Tsuprykov, O.; Chen, X.; Hocher, C.F.; Skoblo, R.; Lianghong, Y.; Hocher, B. Why should we measure free 25(OH) vitamin D? J. Steroid Biochem. Mol. Biol. 2018, 180, 87-104. [CrossRef] [PubMed]

3. Targher, G.; Pichiri, I.; Lippi, G. Vitamin D, thrombosis, and hemostasis: More than skin deep. Semin. Thromb. Hemost. 2012, 38, 114-124. [CrossRef] [PubMed]

4. Jorde, R.; Haug, E.; Figenschau, Y.; Hansen, J.B. Serum levels of vitamin D and haemostatic factors in healthy subjects: The Tromso study. Acta. Haematol. 2007, 117, 91-97. [CrossRef]

5. Chen, Y.; Kong, J.; Sun, T.; Li, G.; Szeto, F.L.; Liu, W.; Deb, D.K.; Wang, Y.; Zhao, Q.; Thadhani, R.; et al. 1,25-Dihydroxyvitamin $\mathrm{D}(3)$ suppresses inflammation-induced expression of plasminogen activator inhibitor-1 by blocking nuclear factor-kappaB activation. Arch. Biochem. Biophys. 2011, 507, $241-247$. [CrossRef]

6. Christakos, S.; Dhawan, P.; Verstuyf, A.; Verlinden, L.; Carmeliet, G. Vitamin D: Metabolism, Molecular Mechanism of Action, and Pleiotropic Effects. Physiol. Rev. 2016, 96, 365-408. [CrossRef]

7. Tripkovic, L.; Lambert, H.; Hart, K.; Smith, C.P.; Bucca, G.; Penson, S.; Chope, G.; Hyppönen, E.; Berry, J.; Vieth, R.; et al. Comparison of vitamin D2 and vitamin D3 supplementation in raising serum 25-hydroxyvitamin D status: A systematic review and meta-analysis. Am. J. Clin. Nutr. 2012, 95, 1357-1364. [CrossRef]

8. Oliveri, B.; Mastaglia, S.R.; Brito, G.M.; Seijo, M.; Keller, G.A.; Somoza, J.; Diez, R.A.; Di Girolamo, G. Vitamin D3 seems more appropriate than D2 to sustain adequate levels of 25OHD: A pharmacokinetic approach. Eur. J. Clin. Nutr. 2015, 69, 697-702. [CrossRef]

9. Houghton, L.A.; Vieth, R. The case against ergocalciferol (vitamin D2) as a vitamin supplement. Am. J. Clin. Nutr. 2006, 84, 694-697. [CrossRef] 
10. Jones, K.S.; Assar, S.; Harnpanich, D.; Bouillon, R.; Lambrechts, D.; Prentice, A.; Schoenmakers, I. 25(OH)D2 half-life is shorter than 25(OH)D3 half-life and is influenced by DBP concentration and genotype. J. Clin. Endocrinol. Metab. 2014, 99, 3373-3381. [CrossRef]

11. Holick, M.F. Vitamin D deficiency. N. Engl. J. Med. 2007, 357, 266-281. [CrossRef] [PubMed]

12. Adams, J.S.; Hewison, M. Update in vitamin D. J. Clin. Endocrinol Metab. 2010, 95, 471-478. [CrossRef] [PubMed]

13. Thacher, T.D.; Clarke, B.L. Vitamin D insufficiency. Mayo Clin. Proc. 2011, 86, 50-60. [CrossRef] [PubMed]

14. Holick, M.F. Resurrection of vitamin D deficiency and rickets. J. Clin. Invest. 2006, 116, 2062-2072. [CrossRef] [PubMed]

15. Sahay, M.; Sahay, R. Rickets-vitamin D deficiency and dependency. Indian J. Endocrinol Metab. 2012, 16, 164-176. [CrossRef]

16. Holick, M.F. High prevalence of vitamin D inadequacy and implications for health. Mayo Clin. Proc. 2006, 81, 353-373. [CrossRef]

17. Aaron, J.E.; Gallagher, J.C.; Anderson, J.; Stasiak, L.; Longton, E.B.; Nordin, B.E.; Nicholson, M. Frequency of osteomalacia and osteoporosis in fractures of the proximal femur. Lancet 1974, 1, 229-233. [CrossRef]

18. Berwick, M.; Armstrong, B.K.; Ben-Porat, L.; Fine, J.; Kricker, A.; Eberle, C.; Barnhill, R. Sun exposure and mortality from melanoma. J. Natl. Cancer Inst. 2005, 97, 195-199. [CrossRef]

19. Krause, R.; Buhring, M.; Hopfenmuller, W.; Holick, M.F.; Sharma, A.M. Ultraviolet B and blood pressure. Lancet 1998, 352, 709-710. [CrossRef]

20. Mathieu, C.; Gysemans, C.; Giulietti, A.; Bouillon, R. Vitamin D and diabetes. Diabetologia 2005, 48, $1247-1257$. [CrossRef]

21. Ritterhouse, L.L.; Crowe, S.R.; Niewold, T.B.; Kamen, D.L.; Macwana, S.R.; Roberts, V.C.; Dedeke, A.B.; Harley, J.B.; Scofield, R.H.; Guthridge, J.M.; et al. Vitamin D deficiency is associated with an increased autoimmune response in healthy individuals and in patients with systemic lupus erythematosus. Ann. Rheum. Dis. 2011, 70, 1569-1574. [CrossRef] [PubMed]

22. Cantorna, M.T.; Mahon, B.D. D-hormone and the immune system. J. Rheumatol Suppl. 2005, 76, 11-20. [PubMed]

23. Arnson, Y.; Amital, H.; Agmon-Levin, N.; Alon, D.; Sanchez-Castanon, M.; Lopez-Hoyos, M.; Matucci-Cerinic, M.; Szucs, G.; Shapira, Y.; Szekanecz, Z.; et al. Serum 25-OH vitamin D concentrations are linked with various clinical aspects in patients with systemic sclerosis: A retrospective cohort study and review of the literature. Autoimmune Rev. 2011, 10, 490-494. [CrossRef] [PubMed]

24. Autier, P.; Gandini, S. Vitamin D supplementation and total mortality: A meta-analysis of randomized controlled trials. Arch. Intern. Med. 2007, 167, 1730-1737. [CrossRef] [PubMed]

25. Grant, W.B.; Cross, H.S.; Garland, C.F.; Gorham, E.D.; Moan, J.; Peterlik, M.; Porojnicu, A.C.; Reichrath, J.; Zittermann, A. Estimated benefit of increased vitamin D status in reducing the economic burden of disease in western Europe. Prog. Biophys. Mol. Biol. 2009, 99, 104-113. [CrossRef]

26. Grant, W.B.; Schwalfenberg, G.K.; Genuis, S.J.; Whiting, S.J. An estimate of the economic burden and premature deaths due to vitamin D deficiency in Canada. Mol. Nutr. Food Res. 2010, 54, 1172-1181. [CrossRef]

27. Forman, J.P.; Giovannucci, E.; Holmes, M.D.; Bischoff-Ferrari, H.A.; Tworoger, S.S.; Willett, W.C.; Curhan, G.C. Plasma 25-hydroxyvitamin D levels and risk of incident hypertension. Hypertension 2007, 49, 1063-1069. [CrossRef]

28. Forman, J.P.; Curhan, G.C.; Taylor, E.N. Plasma 25-hydroxyvitamin D levels and risk of incident hypertension among young women. Hypertension 2008, 52, 828-832. [CrossRef]

29. Brondum-Jacobsen, P.; Benn, M.; Jensen, G.B.; Nordestgaard, B.G. 25-hydroxyvitamin d levels and risk of ischemic heart disease, myocardial infarction, and early death: Population-based study and meta-analyses of 18 and 17 studies. Arterioscler Thromb. Vasc. Biol. 2012, 32, 2794-2802. [CrossRef]

30. Medicine, I.O. Dietary Reference Intakes for Calcium and Vitamin D; The National Academies Press: Washington, DC, USA, 2011; p. 1132.

31. Holick, M.F.; Binkley, N.C.; Bischoff-Ferrari, H.A.; Gordon, C.M.; Hanley, D.A.; Heaney, R.P.; Murad, M.H.; Weaver, C.M. Evaluation, treatment, and prevention of vitamin D deficiency: An Endocrine Society clinical practice guideline. J. Clin. Endocrinol. Metab. 2011, 96, 1911-1930. [CrossRef] 
32. Strugnell, S.A.; Deluca, H.F. The vitamin D receptor-structure and transcriptional activation. Proc. Soc. Exp. Biol. Med. 1997, 215, 223-228. [CrossRef] [PubMed]

33. Sung, C.C.; Liao, M.T.; Lu, K.C.; Wu, C.C. Role of vitamin D in insulin resistance. J. Biomed. Biotechnol. 2012, 2012, 1-11. [CrossRef] [PubMed]

34. Rosen, C.J.; Adams, J.S.; Bikle, D.D.; Black, D.M.; Demay, M.B.; Manson, J.E.; Murad, M.H.; Kovacs, C.S. The non-skeletal effects of vitamin D: An Endocrine Society scientific statement. Endocr. Rev. 2012, 33, 456-492. [CrossRef] [PubMed]

35. Khundmiri, S.J.; Murray, R.D.; Lederer, E. PTH and Vitamin D. Compr. Physiol. 2016, 6, 561-601. [PubMed]

36. Li, Y.C.; Chen, Y.; Du, J. Critical roles of intestinal epithelial vitamin D receptor signaling in controlling gut mucosal inflammation. J. Steroid Biochem. Mol. Biol. 2015, 148, 179-183. [CrossRef] [PubMed]

37. Stumpf, W.E.; Sar, M.; Reid, F.A.; Tanaka, Y.; DeLuca, H.F. Target cells for 1,25-dihydroxyvitamin D3 in intestinal tract, stomach, kidney, skin, pituitary, and parathyroid. Science 1979, 206, 1188-1190. [CrossRef]

38. Adorini, L. Intervention in autoimmunity: The potential of vitamin D receptor agonists. Cell Immunol. 2005, 233, 115-124. [CrossRef]

39. Bhalla, A.K.; Amento, E.P.; Serog, B.; Glimcher, L.H. 1,25-Dihydroxyvitamin D3 inhibits antigen-induced T cell activation. J. Immunol. 1984, 133, 1748-1754.

40. Provvedini, D.M.; Tsoukas, C.D.; Deftos, L.J.; Manolagas, S.C. 1,25-dihydroxyvitamin D3 receptors in human leukocytes. Science 1983, 221, 1181-1183. [CrossRef]

41. Brennan, A.; Katz, D.R.; Nunn, J.D.; Barker, S.; Hewison, M.; Fraher, L.J.; O’Riordan, J.L. Dendritic cells from human tissues express receptors for the immunoregulatory vitamin D3 metabolite, dihydroxycholecalciferol. Immunology 1987, 61, 457-461.

42. Margetic, S. Inflammation and haemostasis. Biochem. Med. (Zagreb) 2012, 22, 49-62. [CrossRef] [PubMed]

43. Franchini, M.; Veneri, D.; Lippi, G. Inflammation and hemostasis: A bidirectional interaction. Clin. Lab. 2007, 53, 63-67. [PubMed]

44. Mackman, N. Triggers, targets and treatments for thrombosis. Nature 2008, 451, 914-918. [CrossRef] [PubMed]

45. Koupenova, M.; Kehrel, B.E.; Corkrey, H.A.; Freedman, J.E. Thrombosis and platelets: An update. Eur. Heart J. 2017, 38, 785-791. [CrossRef] [PubMed]

46. Esmon, C.T. Basic mechanisms and pathogenesis of venous thrombosis. Blood Rev. 2009, 23, $225-229$. [CrossRef]

47. Previtali, E.; Bucciarelli, P.; Passamonti, S.M.; Martinelli, I. Risk factors for venous and arterial thrombosis. Blood Transfus. 2011, 9, 120-138.

48. Franchini, M.; Mannucci, P.M. Association between venous and arterial thrombosis: Clinical implications. Eur. J. Intern. Med. 2012, 23, 333-337. [CrossRef]

49. Agmon-Levin, N.; Blank, M.; Zandman-Goddard, G.; Orbach, H.; Meroni, P.L.; Tincani, A.; Doria, A.; Cervera, R.; Miesbach, W.; Stojanovich, L.; et al. Vitamin D: An instrumental factor in the anti-phospholipid syndrome by inhibition of tissue factor expression. Ann. Rheum. Dis. 2011, 70, 145-150. [CrossRef]

50. Khademvatani, K.; Seyyed-Mohammadzad, M.H.; Akbari, M.; Rezaei, Y.; Eskandari, R.; Rostamzadeh, A. The relationship between vitamin $\mathrm{D}$ status and idiopathic lower-extremity deep vein thrombosis. Int. J. Gen. Med. 2014, 7, 303-309.

51. Wu, W.X.; He, D.R. Low Vitamin D Levels Are Associated With the Development of Deep Venous Thromboembolic Events in Patients With Ischemic Stroke. Clin. Appl. Thromb. Hemost. 2018, 24, 69S-75S. [CrossRef]

52. Nagpal, S.; Na, S.; Rathnachalam, R. Noncalcemic actions of vitamin D receptor ligands. Endocr. Rev. 2005, 26, 662-687. [CrossRef] [PubMed]

53. Palta, S.; Saroa, R.; Palta, A. Overview of the coagulation system. Indian J. Anaesth. 2014, 58, 515-523. [CrossRef] [PubMed]

54. Dehghani, K.; Nowrouzi, A.; Pourdavood, A.H.; Rahmanian, Z. Effect of Vitamin D deficiency extremity and pulmonary venous thromboembolism. Biomed. Res. Ther. 2019, 6, 3107-3112.

55. Korzonek-Szlacheta, I.; Hudzik, B.; Nowak, J.; Szkodzinski, J.; Gasior, M.; Zubelewicz-Szkodzinska, B. Mean platelet volume is associated with serum 25-hydroxyvitamin D concentrations in patients with stable coronary artery disease. Heart Vessels 2018, 33, 1275-1281. [CrossRef] 
56. Blondon, M.; Rodabough, R.J.; Budrys, N.; Johnson, K.C.; Berger, J.S.; Shikany, J.M.; Raiesdana, A.; Heckbert, S.R.; Manson, J.E.; LaCroix, A.Z.; et al. The effect of calcium plus vitamin D supplementation on the risk of venous thromboembolism. Thromb. Haemost. 2015, 113, 999-1009.

57. Aihara, K.; Azuma, H.; Akaike, M.; Ikeda, Y.; Yamashita, M.; Sudo, T.; Hayashi, H.; Yamada, Y.; Endoh, F.; Fujimura, M.; et al. Disruption of nuclear vitamin D receptor gene causes enhanced thrombogenicity in mice. J. Biol. Chem. 2004, 279, 35798-35802. [CrossRef]

58. Ohsawa, M.; Koyama, T.; Yamamoto, K.; Hirosawa, S.; Kamei, S.; Kamiyama, R. 1alpha,25-dihydroxyvitamin $\mathrm{D}(3)$ and its potent synthetic analogs downregulate tissue factor and upregulate thrombomodulin expression in monocytic cells, counteracting the effects of tumor necrosis factor and oxidized LDL. Circulation 2000, 102, 2867-2872. [CrossRef]

59. Martinez-Moreno, J.M.; Herencia, C.; Montes de Oca, A.; Munoz-Castaneda, J.R.; Rodriguez-Ortiz, M.E.; Diaz-Tocados, J.M.; Peralbo-Santaella, E.; Camargo, A.; Canalejo, A.; Rodriguez, M.; et al. Vitamin D modulates tissue factor and protease-activated receptor 2 expression in vascular smooth muscle cells. FASEB J. 2016, 30, 1367-1376. [CrossRef]

60. Wood, J.P.; Ellery, P.E.; Maroney, S.A.; Mast, A.E. Biology of tissue factor pathway inhibitor. Blood 2014, 123, 2934-2943. [CrossRef]

61. Topaloglu, O.; Arslan, M.S.; Karakose, M.; Ucan, B.; Ginis, Z.; Cakir, E.; Akkaymak, E.T.; Sahin, M.; Ozbek, M.; Cakal, E.; et al. Is there any association between thrombosis and tissue factor pathway inhibitor levels in patients with vitamin D deficiency? Clin. Appl. Thromb. Hemost. 2015, 21, 428-433. [CrossRef]

62. Toderici, M.; de la Morena-Barrio, M.E.; Padilla, J.; Minano, A.; Anton, A.I.; Iniesta, J.A.; Herranz, M.T.; Fernandez, N.; Vicente, V.; Corral, J. Identification of Regulatory Mutations in SERPINC1 Affecting Vitamin D Response Elements Associated with Antithrombin Deficiency. PLoS ONE 2016, 11, e0152159.

63. Silvagno, F.; De Vivo, E.; Attanasio, A.; Gallo, V.; Mazzucco, G.; Pescarmona, G. Mitochondrial localization of vitamin D receptor in human platelets and differentiated megakaryocytes. PLoS ONE 2010, 5, e8670. [CrossRef] [PubMed]

64. Drake, T.A.; Morrissey, J.H.; Edgington, T.S. Selective cellular expression of tissue factor in human tissues: Implications for disorders of hemostasis and thrombosis. Am. J. Pathol. 1989, 134, 1087-1097. [PubMed]

65. Giesen, P.L.; Rauch, U.; Bohrmann, B.; Kling, D.; Roque, M.; Fallon, J.T.; Badimon, J.J.; Himber, J.; Riederer, M.A.; Nemerson, Y. Blood-borne tissue factor: Another view of thrombosis. Proc. Natl. Acad. Sci. USA 1999, 96, 2311-2315. [CrossRef]

66. Braekkan, S.K.; Mathiesen, E.B.; Njølstad, I.; Wilsgaard, T.; Størmer, J.; Hansen, J.B. Mean platelet volume is a risk factor for venous thromboembolism: The Tromsø study. J. Thromb. Haemost. 2010, 8, 157-162. [CrossRef] [PubMed]

67. Engelmann, B.; Massberg, S. Thrombosis as an intravascular effector of innate immunity. Nat. Rev. Immunol. 2013, 13, 34-45. [CrossRef] [PubMed]

68. Gupta, N.; Sahu, A.; Prabhakar, A.; Chatterjee, T.; Tyagi, T.; Kumari, B.; Khan, N.; Nair, V.; Bajaj, N.; Sharma, M.; et al. Activation of NLRP3 inflammasome complex potentiates venous thrombosis in response to hypoxia. Proc. Natl. Acad. Sci. USA 2017, 114, 4763-4768. [CrossRef]

69. Yadav, V.; Chi, L.; Zhao, R.; Tourdot, B.E.; Yalavarthi, S.; Jacobs, B.N.; Banka, A.; Liao, H.; Koonse, S.; Anyanwu, A.C.; et al. ENTPD-1 disrupts inflammasome IL-1 $\beta$-driven venous thrombosis. J. Clin. Investig. 2019, 129, 2872-2877. [CrossRef]

70. Ali, R.A.; Wuescher, L.M.; Worth, R.G. Platelets: Essential components of the immune system. Curr. Trends Immunol. 2015, 16, 65-78.

71. von Brühl, M.L.; Stark, K.; Steinhart, A.; Chandraratne, S.; Konrad, I.; Lorenz, M.; Khandoga, A.; Tirniceriu, A.; Coletti, R.; Köllnberger, M.; et al. Monocytes, neutrophils, and platelets cooperate to initiate and propagate venous thrombosis in mice in vivo. J. Exp. Med. 2012, 209, 819-835. [CrossRef]

72. Morrell, C.N.; Aggrey, A.A.; Chapman, L.M.; Modjeski, K.L. Emerging roles for platelets as immune and inflammatory cells. Blood 2014, 123, 2759-2767.

73. Luyendyk, J.P.; Schoenecker, J.G.; Flick, M.J. The multifaceted role of fibrinogen in tissue injury and inflammation. Blood 2018, 133, 511-520.

74. Hewison, M. Vitamin D and the immune system: New perspectives on an old theme. Endocrinol. Metab. Clin. North Am. 2010, 39, 365-379. [CrossRef] [PubMed] 
75. Hewison, M.; Freeman, L.; Hughes, S.V.; Evans, K.N.; Bland, R.; Eliopoulos, A.G.; Kilby, M.D.; Moss, P.A.; Chakraverty, R. Differential regulation of vitamin D receptor and its ligand in human monocyte-derived dendritic cells. J. Immunol. 2003, 170, 5382-5390. [CrossRef]

76. Cantorna, M.T.; Snyder, L.; Lin, Y.D.; Yang, L. Vitamin D and 1,25(OH)2D regulation of T cells. Nutrients 2015, 7, 3011-3021. [CrossRef]

77. Zhang, Y.; Leung, D.Y.; Richers, B.N.; Liu, Y.; Remigio, L.K.; Riches, D.W.; Goleva, E. Vitamin D inhibits monocyte/macrophage proinflammatory cytokine production by targeting MAPK phosphatase-1. J. Immunol. 2012, 188, 2127-2135. [CrossRef]

78. Schardey, J.; Globig, A.M.; Janssen, C.; Hofmann, M.; Manegold, P.; Thimme, R.; Hasselblatt, P. Vitamin D inhibits pro-inflammatory $\mathrm{T}$ cell function in patients with inflammatory bowel disease. J. Crohns Colitis 2019. [CrossRef]

79. Yu, X.P.; Bellido, T.; Manolagas, S.C. Down-regulation of NF-kappa B protein levels in activated human lymphocytes by 1,25-dihydroxyvitamin D3. Proc. Natl. Acad. Sci. USA 1995, 92, 10990-10994. [CrossRef]

80. Wu, K.K.; Thiagarajan, P. Role of endothelium in thrombosis and hemostasis. Annu. Rev. Med. 1996, 47, 315-331.

81. Bunting, S.; Moncada, S.; Vane, J.R. Antithrombotic properties of vascular endothelium. Lancet 1977, 2, 1075-1076. [CrossRef]

82. Bochkov, V.N.; Mechtcheriakova, D.; Lucerna, M.; Huber, J.; Malli, R.; Graier, W.F.; Hofer, E.; Binder, B.R.; Leitinger, N. Oxidized phospholipids stimulate tissue factor expression in human endothelial cells via activation of ERK/EGR-1 and Ca ${ }^{2+} /$ NFAT. Blood 2002, 99, 199-206. [CrossRef] [PubMed]

83. Colucci, M.; Balconi, G.; Lorenzet, R.; Pietra, A.; Locati, D.; Donati, M.B.; Semeraro, N. Cultured human endothelial cells generate tissue factor in response to endotoxin. J. Clin. Investig. 1983, 71, 1893-1896. [CrossRef] [PubMed]

84. Yau, J.W.; Teoh, H.; Verma, S. Endothelial cell control of thrombosis. BMC Cardiovasc. Disord. 2015, 15, 130. [CrossRef] [PubMed]

85. Ertek, S.; Akgul, E.; Cicero, A.F.; Kutuk, U.; Demirtas, S.; Cehreli, S.; Erdogan, G. 25-Hydroxy vitamin D levels and endothelial vasodilator function in normotensive women. Arch. Med. Sci. 2012, 8, 47-52. [CrossRef] [PubMed]

86. Harris, R.A.; Pedersen-White, J.; Guo, D.H.; Stallmann-Jorgensen, I.S.; Keeton, D.; Huang, Y.; Shah, Y.; Zhu, H.; Dong, Y. Vitamin D3 supplementation for 16 weeks improves flow-mediated dilation in overweight African-American adults. Am. J. Hypertens. 2011, 24, 557-562. [CrossRef] [PubMed]

87. Sugden, J.A.; Davies, J.I.; Witham, M.D.; Morris, A.D.; Struthers, A.D. Vitamin D improves endothelial function in patients with Type 2 diabetes mellitus and low vitamin D levels. Diabet. Med. 2008, 25, 320-325. [CrossRef] [PubMed]

88. Tarcin, O.; Yavuz, D.G.; Ozben, B.; Telli, A.; Ogunc, A.V.; Yuksel, M.; Toprak, A.; Yazici, D.; Sancak, S.; Deyneli, O.; et al. Effect of vitamin D deficiency and replacement on endothelial function in asymptomatic subjects. J. Clin. Endocrinol. Metab. 2009, 94, 4023-4030. [CrossRef]

89. Schleithoff, S.S.; Zittermann, A.; Tenderich, G.; Berthold, H.K.; Stehle, P.; Koerfer, R. Vitamin D supplementation improves cytokine profiles in patients with congestive heart failure: A double-blind, randomized, placebo-controlled trial. Am. J. Clin. Nutr. 2006, 83, 754-759. [CrossRef]

90. Molinari, C.; Uberti, F.; Grossini, E.; Vacca, G.; Carda, S.; Invernizzi, M.; Cisari, C. $1 \alpha, 25$-dihydroxycholecalciferol induces nitric oxide production in cultured endothelial cells. Cell Physiol. Biochem. 2011, 27, 661-668. [CrossRef]

91. Urena-Torres, P.; Metzger, M.; Haymann, J.P.; Karras, A.; Boffa, J.J.; Flamant, M.; Vrtovsnik, F.; Gauci, C.; Froissart, M.; Houillier, P.; et al. Association of kidney function, vitamin D deficiency, and circulating markers of mineral and bone disorders in CKD. Am. J. Kidney Dis. 2011, 58, 544-553. [CrossRef]

92. Jablonski, K.L.; Chonchol, M.; Pierce, G.L.; Walker, A.E.; Seals, D.R. 25-Hydroxyvitamin D deficiency is associated with inflammation-linked vascular endothelial dysfunction in middle-aged and older adults. Hypertension 2011, 57, 63-69. [CrossRef] [PubMed]

93. Rahman, A.; Fazal, F. Blocking NF-kappaB: An inflammatory issue. Proc. Am. Thorac. Soc. 2011, 8, 497-503. [CrossRef] [PubMed]

94. Sprague, A.H.; Khalil, R.A. Inflammatory cytokines in vascular dysfunction and vascular disease. Biochem. Pharmacol. 2009, 78, 539-552. [CrossRef] [PubMed] 
95. Rahman, A.; Anwar, K.N.; True, A.L.; Malik, A.B. Thrombin-induced p65 homodimer binding to downstream NF-kappa B site of the promoter mediates endothelial ICAM-1 expression and neutrophil adhesion. J. Immunol. 1999, 162, 5466-5476. [PubMed]

96. Sugama, Y.; Tiruppathi, C.; offakidevi, K.; Andersen, T.T.; Fenton, J.W., 2nd; Malik, A.B. Thrombin-induced expression of endothelial P-selectin and intercellular adhesion molecule-1: A mechanism for stabilizing neutrophil adhesion. J. Cell Biol. 1992, 119, 935-944. [CrossRef]

97. Xue, J.; Thippegowda, P.B.; Hu, G.; Bachmaier, K.; Christman, J.W.; Malik, A.B.; Tiruppathi, C. NF-кB regulates thrombin-induced ICAM-1 gene expression in cooperation with NFAT by binding to the intronic NF-kappaB site in the ICAM-1 gene. Physiol. Genom. 2009, 38, 42-53. [CrossRef] [PubMed]

98. Merke, J.; Milde, P.; Lewicka, S.; Hugel, U.; Klaus, G.; Mangelsdorf, D.J.; Haussler, M.R.; Rauterberg, E.W.; Ritz, E. Identification and regulation of 1,25-dihydroxyvitamin D3 receptor activity and biosynthesis of 1,25-dihydroxyvitamin D3: Studies in cultured bovine aortic endothelial cells and human dermal capillaries. J. Clin. Invest. 1989, 83, 1903-1915. [CrossRef]

99. Martinez-Miguel, P.; Valdivielso, J.M.; Medrano-Andres, D.; Roman-Garcia, P.; Cano-Penalver, J.L.; Rodriguez-Puyol, M.; Rodriguez-Puyol, D.; Lopez-Ongil, S. The active form of vitamin D, calcitriol, induces a complex dual upregulation of endothelin and nitric oxide in cultured endothelial cells. Am. J. Physiol. Endocrinol. Metab. 2014, 307, E1085-E1096. [CrossRef]

100. Gibson, C.C.; Davis, C.T.; Zhu, W.; Bowman-Kirigin, J.A.; Walker, A.E.; Tai, Z.; Thomas, K.R.; Donato, A.J.; Lesniewski, L.A.; Li, D.Y. Dietary Vitamin D and Its Metabolites Non-Genomically Stabilize the Endothelium. PLoS ONE 2015, 10, e0140370. [CrossRef]

101. Ni, W.; Watts, S.W.; Ng, M.; Chen, S.; Glenn, D.J.; Gardner, D.G. Elimination of vitamin D receptor in vascular endothelial cells alters vascular function. Hypertension 2014, 64, 1290-1298. [CrossRef]

102. Al Mheid, I.; Patel, R.; Murrow, J.; Morris, A.; Rahman, A.; Fike, L.; Kavtaradze, N.; Uphoff, I.; Hooper, C.; Tangpricha, V.; et al. Vitamin D status is associated with arterial stiffness and vascular dysfunction in healthy humans. J. Am. Coll. Cardiol. 2011, 58, 186-192. [CrossRef] [PubMed]

103. Zhang, Z.; Sun, L.; Wang, Y.; Ning, G.; Minto, A.W.; Kong, J.; Quigg, R.J.; Li, Y.C. Renoprotective role of the vitamin D receptor in diabetic nephropathy. Kidney Int. 2008, 73, 163-171. [CrossRef] [PubMed]

104. Li, Y.C.; Kong, J.; Wei, M.; Chen, Z.F.; Liu, S.Q.; Cao, L.P. 1,25-Dihydroxyvitamin D(3) is a negative endocrine regulator of the renin-angiotensin system. J. Clin. Invest. 2002, 110, 229-238. [CrossRef] [PubMed]

105. Tomaschitz, A.; Pilz, S.; Ritz, E.; Grammer, T.; Drechsler, C.; Boehm, B.O.; Marz, W. Independent association between 1,25-dihydroxyvitamin D, 25-hydroxyvitamin D and the renin-angiotensin system: The Ludwigshafen Risk and Cardiovascular Health (LURIC) study. Clin. Chim. Acta. 2010, 411, 1354-1360. [CrossRef] [PubMed]

106. Vaidya, A.; Forman, J.P.; Hopkins, P.N.; Seely, E.W.; Williams, J.S. 25-Hydroxyvitamin D is associated with plasma renin activity and the pressor response to dietary sodium intake in Caucasians. J. Renin Angiotensin Aldosterone Syst. 2011, 12, 311-319. [CrossRef] [PubMed]

107. Carrara, D.; Bruno, R.M.; Bacca, A.; Taddei, S.; Duranti, E.; Ghiadoni, L.; Bernini, G. Cholecalciferol treatment downregulates renin-angiotensin system and improves endothelial function in essential hypertensive patients with hypovitaminosid D. J. Hypertens. 2016, 34, 2199-2205. [CrossRef] [PubMed]

108. Xu, W.; Hu, X.; Qi, X.; Zhu, R.; Li, C.; Zhu, Y.; Yin, S.; Cheng, L. Vitamin D Ameliorates Angiotensin II-Induced Human Endothelial Progenitor Cell Injury via the PPAR-gamma/HO-1 Pathway. J. Vasc. Res. 2019, 56, $17-27$. [CrossRef]

109. Honda, A.; Matsuura, K.; Fukushima, N.; Tsurumi, Y.; Kasanuki, H.; Hagiwara, N. Telmisartan induces proliferation of human endothelial progenitor cells via PPARgamma-dependent PI3K/Akt pathway. Atherosclerosis 2009, 205, 376-384. [CrossRef]

110. Han, T.; Liu, M.; Yang, S. DJ-1 Alleviates Angiotensin II-Induced Endothelial Progenitor Cell Damage by Activating the PPARgamma/HO-1 Pathway. J. Cell Biochem. 2018, 119, 392-400. [CrossRef]

111. Liang, B.; Wang, X.; Zhang, N.; Yang, H.; Bai, R.; Liu, M.; Bian, Y.; Xiao, C.; Yang, Z. Angiotensin-(1-7) Attenuates Angiotensin II-Induced ICAM-1, VCAM-1, and MCP-1 Expression via the MAS Receptor Through Suppression of P38 and NF-kappaB Pathways in HUVECs. Cell Physiol. Biochem. 2015, 35, 2472-2482. [CrossRef] 
112. Schroder-Heurich, B.; von Hardenberg, S.; Brodowski, L.; Kipke, B.; Meyer, N.; Borns, K.; von Kaisenberg, C.S.; Brinkmann, H.; Claus, P.; von Versen-Hoynck, F. Vitamin D improves endothelial barrier integrity and counteracts inflammatory effects on endothelial progenitor cells. FASEB J. 2019. [CrossRef] [PubMed]

113. Hejazi, M.E.; Modarresi-Ghazani, F.; Hamishehkar, H.; Mesgari-Abbasi, M.; Dousti, S.; Entezari-Maleki, T. The Effect of Treatment of Vitamin D Deficiency on the Level of P-Selectin and hs-CRP in Patients With Thromboembolism: A Pilot Randomized Clinical Trial. J. Clin. Pharmacol. 2017, 57, 40-47. [CrossRef] [PubMed]

114. Chitalia, N.; Ismail, T.; Tooth, L.; Boa, F.; Hampson, G.; Goldsmith, D.; Kaski, J.C.; Banerjee, D. Impact of vitamin D supplementation on arterial vasomotion, stiffness and endothelial biomarkers in chronic kidney disease patients. PLoS ONE 2014, 9, e91363. [CrossRef] [PubMed]

115. Lindqvist, P.G.; Epstein, E.; Olsson, H. Does an active sun exposure habit lower the risk of venous thrombotic events? A D-lightful hypothesis. J. Thromb. Haemost. 2009, 7, 605-610. [CrossRef]

116. Tangpricha, V.; Turner, A.; Spina, C.; Decastro, S.; Chen, T.C.; Holick, M.F. Tanning is associated with optimal vitamin D status (serum 25-hydroxyvitamin D concentration) and higher bone mineral density. Am. J. Clin. Nutr. 2004, 80, 1645-1649. [CrossRef]

117. Brot, C.; Vestergaard, P.; Kolthoff, N.; Gram, J.; Hermann, A.P.; Sorensen, O.H. Vitamin D status and its adequacy in healthy Danish perimenopausal women: Relationships to dietary intake, sun exposure and serum parathyroid hormone. Br. J. Nutr. 2001, 86, S97-S103. [CrossRef]

118. Beer, T.M.; Venner, P.M.; Ryan, C.W.; Petrylak, D.P.; Chatta, G.; Dean Ruether, J.; Chi, K.N.; Curd, J.G.; DeLoughery, T.G. High dose calcitriol may reduce thrombosis in cancer patients. Br. J. Haematol. 2006, 135, 392-394. [CrossRef]

119. Stricker, H.; TosiBianda, F.; Guidicelli-Nicolosi, S.; Limoni, C.; Colucci, G. Effect of a single, oral, high-dose vitamin D supplementation on endothelial function in patients with peripheral arterial disease: A randomised controlled pilot study. Eur. J. Vasc. Endovasc. Surg. 2012, 44, 307-312. [CrossRef]

120. Witham, M.D.; Dove, F.J.; Khan, F.; Lang, C.C.; Belch, J.J.; Struthers, A.D. Effects of vitamin D supplementation on markers of vascular function after myocardial infarction-A randomised controlled trial. Int. J. Cardiol. 2013, 167, 745-749. [CrossRef]

121. Tyagi, T.; Ahmad, S.; Gupta, N.; Sahu, A.; Ahmad, Y.; Nair, V.; Chatterjee, T.; Bajaj, N.; Sengupta, S.; Ganju, L.; et al. Altered expression of platelet proteins and calpain activity mediate hypoxia-induced prothrombotic phenotype. Blood 2014, 123, 1250-1260. [CrossRef]

122. Kapil, U.; Pandey, R.M.; Goswami, R.; Sharma, B.; Sharma, N.; Ramakrishnan, L.; Singh, G.; Sareen, N.; Sati, H.C.; Gupta, A.; et al. Prevalence of Vitamin D deficiency and associated risk factors among children residing at high altitude in Shimla district, Himachal Pradesh, India. Indian J. Endocrinol. Metab. 2017, 21, 178-183. [CrossRef] [PubMed]

(C) 2019 by the authors. Licensee MDPI, Basel, Switzerland. This article is an open access article distributed under the terms and conditions of the Creative Commons Attribution (CC BY) license (http://creativecommons.org/licenses/by/4.0/). 